\title{
Tolerance of Genetically Distant Cotton Hybrids to Cotton Bollworm (Helicoverpa Armigera) in Depending of the Level of (+)- Gossypol in Seeds
}

\author{
Ikrom Amanturdiev, Sayfulla Boboyev, Mirvakhob Mirakhmedov, Akhmedjanova Gulnoza \\ Department of Biology, National University of Uzbekistan named after Mirzo Ulugbek, Tashkent, \\ Uzbekistan. \\ amanturdiyev.i@gmail.com
}

Received: February 6, 2020. Revised: May 21, 2020. 2nd Revised: August 10, 2020. Accepted: August 17, 2020. Published: August 17, 2020.

\begin{abstract}
In this paper presents obtained data on the natural background about on tolerance of senior generations of cotton hybrids to cotton bollworm (Helicoverpa armigera) with different levels of $(+)$ gossypol in seeds. On the basis was obtained results, revealed that the level of (+) - gossypol in seeds does not significantly resistance to cotton bollworm, i.e. Confirmed the possibility of selecting new broods and lines of cotton with different levels $(+)$ - gossypol and tolerance to Helicoverpa armigera. Results of researches of comparative resistance to Helicoverpa armigera among hybrids of different generations in petri dishes, it was established that progenies with a different levels of $(+)$ - gossypol, a definite pattern is observed for affection. Genotypes with a low level of (+)- gossypol are affected by Helicoverpa armigera to a certain extent less than hybrids with high (+)-gossypol level. Although, the incidence of the initial accession $\mathrm{BC}_{3} \mathrm{~S}_{1}$-1-6-3-15 of US with a high level of gossypol does not preclude the possibility of developing of resistant genotypes with a high level of (+)-gossypol, which requires additional researches in this direction.
\end{abstract}

Key words: cotton, gossypol, damage, generation, Helicoverpa armigera, hybridization, bolls, resistance, seeds.

Scientific area: Life Science, Plant science.

\section{INTRODUCTION}

Cottonseed provides a high quality protein that is currently under utilized because of the presence of a toxic compound called gossypol. Gossypol is biosynthesized by the free radical coupling of two molecules of hemigossypol. During this coupling reaction, two optically active enantiomers are formed. One of these is referred to as (+)-gossypol and the other as (-)-gossypol. In cotton (Gossypium) the ratio of (+)- to (-)-gossypol can vary from 98:2 to 31:69 in seed (Cass et al., 1991; Percy et al., 1996). Within the genus Gossypium, were found accessions from several species that have $>92 \%(+)$ gossypol in the seed. These include G.mustelinum, G. anomalum, and G.gossypioides (Stipanovic et al., 2005). Cass et al. (1991) first reported that G. barbadense had an excess of the (-)-enantiomer in the seed. It was found that some accessions of G.darwinii, G.sturtianum, G.harknessii, G.longicalyx and G.costulatum also produce an excess of (-)-gossypol in the seed (Stipanovic et al., 2005) [1].
Gossypol, which is found in pigment glands, was identified in 1915 (Withers and Carruth) as the toxic component in cottonseed. Bottger et al. (1964) showed that gossypol was toxic to cotton aphids, lygus bugs, saltmarsh caterpillars, thurberia weevils, and bollworms. Jenkins et al. (1966) showed that the grape colaspis and leaf beetle preferred feeding on glandless compared to glanded cotton cultivars. Gossypol inhibits the growth and development of many insect pests including the beet armyworm, bollworm, cabbage looper and the salt-marsh caterpillar (Bottger and Patana, 1966) [2].

Terpenoids that are biosynthetically related to gossypol also occur in the foliage. Besides gossypol, these terpenes include hemigossypolone and heliocides $\mathrm{H}_{1}, \mathrm{H}_{2}$, $\mathrm{H}_{3}$ and $\mathrm{H}_{4}$ (Gray et al., 1976; Stipanovic et al., 1977a; 1977b; 1978a; 1978b). These compounds are also involved in insect resistance. In an artificial diet study, Stipanovic and collaborators established the effective dosage that is required to reduce growth of the tobacco budworm larvae (Heliothis virescens (F.) by 50\% ( $\left.\mathrm{ED}_{50}\right)$ (Stipanovic et al., 1977a; Williams et al., 1987). Although gossypol is toxic, field studies show that the levels of heliocides and hemigossypolone correlate better with resistance than gossypol (Hedin et al., 1992; Jenkins, 1995) [3].

Cotton bollworm (Helicoverpa armigera), the main rodent pests. In particular, the elements of the cotton bollworm moth is a great loss, he is the glory and the loss of knots, dry or completely fall (Rashidov, 1982) [4]. Zhang Jhin (1985) study carried out at the United States that the resistance of cotton bollworm and sucking pests in addition to the gossypol, along with other terpenoid compounds, flavonoids, fatty acids and tannin material is provided [5]. Thus, gossypol does not appear to be the primary source of chemical resistance to Helicoverpa in cotton foliage.

Extensive tests on the toxicity of $(+)$ - and (-)-gossypol to insect pests are not available. Chinese scientists report a study with Helicoverpa armigera in which larvae were raised on artificial diets containing either (+)- or (-)-gossypol from the $3^{\text {rd }}$ instar through pupation to the moth stage (Yang et al., 1999) [6]. The larvae raised on the $(+)$-gossypol diet matured more slowly, and percent survival to the adult was lower. Stipanovic et al. (2006) showed that racemic, (+)- and (-)gossypol were equally effective at reducing days-topupation, pupal weights and survival of Heliothis zea. Stipanovic et al. (2006) showed that the leaves and stems of $G$. hirsutum marie galante that exhibit high levels of 
$(+)$-gossypol in the seed falls within the normal 3:2 range. Thus, regulation of the $(+)$ - to $(-)$-gossypol ratio in foliage appears to be under separate regulation from that in seed. Therefore, we expect the plants exhibiting a high level of $(+)$-gossypol in the seed to behave normally with respect to susceptibility to phytophagous insects [7].

More than a decade ago, scientists at the USDA, Cotton Pathology Research Unit, Southern Plains Agricultural Research Center in College Station, Texas began a backcross breeding program to incorporate the high (+)-gossypol trait from moco cotton into agronomically acceptable cotton cultivars. This backcross breeding program shows two dominant genes are responsible for the high percentages of $(+)$-gossypol in moco cottonseed (Bell et al., 2000).

\section{MATERIALS AND METHODS}

Materials of researches were served medium fiber kind ( $G$. hirsutum L.) and thin fiber kind ( $G$. barbadense L.) cotton cultivars, lines and accessions of the US with high level of $(+)$ gossypol, as well as hybrids obtained with their participation. The degree of damage by bollworm (Helicoverpa armigera) and its butterfly in artificial (isolated background) and field conditions was determined by the method of L.P. Shvetsova, E. Em (1991); assessment of the degree of damage to the bollworm in different hybrid generations in the laboratory according to N.Sattarov and I.Amanturdiev (2014); determination of the level of $(+)$ - gossypol on an HPLC instrument according to Hron et al. (1999); mathematical, statistical (MS Excel) and carried out according to B.P. Dospekhov (1985). Research work was carried out in 2016-2018, in particular, field and artificial experiments were carried out in the laboratory "Genetics and cytology of cotton" of the Research Institute of breeding and seed production, at the National University of Uzbekistan, and laboratory experiments at the Institute for Plant Protection.

By joint researches of USDA and Uzbek scientists under KX-EA-KX-2018-65 and Uzb2-31001-TA-08 projects toward developing of cultivars that exhibit a high ratio of (+)-gossypol in the seed by using of Uzbek cultivars and American lines has shown that: it is possibility to transfer the high (+)-gossypol seed trait from U.S. cotton accessions into Uzbek cultivars; these Uzbek cotton hybrids developed to date have $>93 \%(+)$-gossypol. Thus, it is possible to introduce the high $(+)$-gossypol seed trait into Uzbek cotton lines to provide plants with agronomic traits suitable for growing in Uzbekistan; these plants are no more susceptible to insect pests and pathogens than normal cotton cultivars.

In the current years of researches investigate the character of inheritance and variability of insect resistance and evaluation of developed progenies for resistance to Helicoverpa armigera in artificial conditions, the total of gossypol and $(+)$-gossypol in seeds and other important parameters of various hybrid generations of cotton [8-10].

\section{RESULTS AND DISCUSSIONS}

It is known that hybridization is a major source of genetic variation in populations. The resulting random chromosome segregation at meiosis, involving diverse parental forms, leads to the recombination of genetic materials. In the selection of crops, including cotton, different methods of interspecific hybridization are exploited to produce a wide variability in economically valuable traits and to develop nonexistent combinations.

The goal of our researches is to develop new initial materials with a high level of $(+)$ - gossypol in seeds and tolerant to bollworm based on the study of tolerance to bollworm hybrids obtained with the participation of cotton cultivars with different levels and forms of gossypol in seeds. Based on the above researches, we will analyse in this paper some research results regarding to Helicoverpa armigera tolerance of progenies developed with the participation of genetically distant hybridization.

The results of the first observation of the first set of hybrids under isolated conditions showed that the $\mathrm{F}_{4} \mathrm{BC}_{3} \mathrm{~S}_{1}-47-8-1-17 \times$ S-6532 with the level of $(+)-$ gossypol $91.4 \%$ was not affected by Helicoverpa armigera (Table 1). Among the studied only in the combination $\mathrm{F}_{4} \mathrm{BC}_{3} \mathrm{~S}_{1}-47-8-1-17$ x S-6524 with a high level of $(+)-$ gossypol (91.2\%), a relatively high affection with Helicoverpa armigera was observed. In the remaining cases, there was no significant. The second observation of the damage of plants with a different level of $(+)$-gossypol in seeds showed resistance of high $(+)$ - gossypol (91.4\%) progenies to Helicoverpa armigera. It should be noted that all combinations with the level of $(+)$-gossypol over $91 \%$, in contrast to the ybrids of the progenies with a low level of (+) - gossypol, were less affected (5 and lower percentages). The results of the 3-observation of the damage by Helicoverpa armigera showed that the pest is being moved in depending of the level of (+)-gossypol. In other words, among the hybrids of this generation with a high level of trait, only in two cases, i.e. in the combinations $\mathrm{F}_{4} \mathrm{BC}_{3} \mathrm{~S}_{1}-47-8-1-17$ x S-6524 and $\mathrm{F}_{4} \mathrm{BC}_{3} \mathrm{~S}_{1}$ 1-6-3-15 x S-6524, the damage were observed at the level $15 \%$ and $10 \%$, respectively. The remaining progenies were affected up to $5 \%$. However, the percentage of affection with Helicoverpa armigera increased (except for the combination $\mathrm{F}_{4} \mathrm{BC}_{3} \mathrm{~S}_{1}-47-8-1-17 \times \mathrm{S}-6530$ ) at hybrids with a relatively low level of $(+)$-gossypol.

The results of first observation of hybrids $\mathrm{F}_{6}$ under the conditions of a greenhouse, showed that all combinations with both a high (above 90\%) and low (below 70\%) level of $(+)$ - gossypol were affected by Helicoverpa armigera (Table 2). Among the studied, the hybrid $\mathrm{F}_{6} \mathrm{BC}_{3} \mathrm{~S}_{1}-1-6-3-15 \times \mathrm{S}-6530$ with a relatively high content of $(+)$ - gossypol (90.8\%), was less affected $(6 \%)$. The results of monitoring of susceptibility to Helicoverpa armigera at the first observation showed that the pest is populated depending on the level of $(+)$-gossypol. In other words, among $\mathrm{F}_{6}$ hybrids with a high level of $(+)$ gossypol, only in two cases, i.e. at $\mathrm{F}_{6} \mathrm{~L}-10 / 04 \times \mathrm{BC}_{3} \mathrm{~S}_{1}-47$ 8-1-17 and $\mathrm{F}_{6} \mathrm{BC}_{3} \mathrm{~S}_{1}-1-6-3-15$ x S-6524, a high degree of sussceptibility were observed $(23 \%$ and $21 \%$, respectively). It can be noted that hybrids of this generation with a high level of $(+)$ - gossypol were affected by $H$. armigera from $6 \%\left(\mathrm{~F}_{6} \mathrm{BC}_{3} \mathrm{~S}_{1}-1-6-3-15 \times \mathrm{S}\right.$ $6530)$ up to $17 \%\left(\mathrm{~F}_{6} \mathrm{BC}_{3} \mathrm{~S}_{1}-47-8-1-17 \times \mathrm{S}-6532\right)$. Thus, it was found that the studied progenies $\mathrm{F}_{6}$ with high $(+)-$ gossypol were relatively resistant to the cotton bollworm 
in comparing to progenies with low level $(+)$-gossypol.

These results indicate that the level of $(+)$-gossypol does not significantly affect on resistance to H.armigera.

Table 1. Dynamics of affection of cotton hybrids $\mathrm{F}_{4}$ by Helicoverpa armigera

\begin{tabular}{|c|c|c|c|c|c|c|c|c|c|c|c|c|}
\hline \multirow{3}{*}{ № } & \multirow{3}{*}{ Hybrids-combinations } & \multirow{3}{*}{ 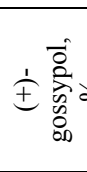 } & \multirow{3}{*}{ 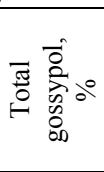 } & \multicolumn{4}{|c|}{ 1-Observation } & \multicolumn{4}{|c|}{ 2-Observation } & \multirow{3}{*}{$\begin{array}{l}\text { 3-Observation } \\
\text { Affected, } \%\end{array}$} \\
\hline & & & & \multicolumn{3}{|c|}{$\begin{array}{l}\text { Density of population, } 10 \\
\text { plants,n }\end{array}$} & \multirow[t]{2}{*}{$\begin{array}{c}\text { Affected, } \\
\%\end{array}$} & \multicolumn{3}{|c|}{$\begin{array}{c}\text { Density of population, } 10 \\
\text { plants, } \mathrm{n}\end{array}$} & \multirow[t]{2}{*}{$\begin{array}{c}\text { Affected, } \\
\%\end{array}$} & \\
\hline & & & & $\begin{array}{c}\text { Eggs, } \\
\mathrm{n}\end{array}$ & $\begin{array}{l}\text { Caterpi } \\
\text { llars,n }\end{array}$ & $\begin{array}{l}\text { Affected } \\
\text { buds, } n\end{array}$ & & $\begin{array}{c}\text { Eggs } \\
, \mathrm{n}\end{array}$ & $\begin{array}{l}\text { Caterpi } \\
\text { llars,n }\end{array}$ & $\begin{array}{c}\text { Affected } \\
\text { buds, } \mathrm{n}\end{array}$ & & \\
\hline 2 & $\mathrm{~F}_{4} \mathrm{BC}_{3} \mathrm{~S}_{1}-47-8-1-17 \times \mathrm{S}-6530$ & 71.9 & 0.46 & 0.05 & 0 & 0 & 5.0 & 0.05 & 0 & 0.05 & 5.0 & 5.0 \\
\hline 3 & $\mathrm{~F}_{4} \mathrm{BC}_{3} \mathrm{~S}_{1}-47-8-1-17 \times \mathrm{S}-6532$ & 75.6 & 2.03 & 0.15 & 0 & 0.05 & 15.0 & 0.05 & 0 & 0.1 & 5.0 & 10.0 \\
\hline 4 & $\mathrm{~F}_{4} \mathrm{BC}_{3} \mathrm{~S}_{1}-1-6-3-15 \times \mathrm{S}-6524$ & 76.7 & 1.36 & 0.05 & 0 & 0 & 5.0 & 0.05 & 0.05 & 0.05 & 10.0 & 10.0 \\
\hline 5 & $\mathrm{~F}_{4} \mathrm{BC}_{3} \mathrm{~S}_{1}-1-6-3-15 \times$ x-6530 & 75.2 & 1.20 & 0.15 & 0 & 0 & 15.0 & 0.05 & 0.05 & 0.15 & 10.0 & 10.0 \\
\hline 8 & $\mathrm{~F}_{4} \mathrm{BC}_{3} \mathrm{~S}_{1}-47-8-1-17 \times \mathrm{S}-6530$ & 92.1 & 1.35 & 0.05 & 0 & 0.1 & 5.0 & 0.05 & 0 & 0.1 & 5.0 & 5.0 \\
\hline 9 & $\mathrm{~F}_{4} \mathrm{BC}_{3} \mathrm{~S}_{1}-47-8-1-17 \times \mathrm{S}-6532$ & 91.4 & 0.79 & 0 & 0 & 0 & 0 & 0 & 0 & 0 & 0 & 5.0 \\
\hline 10 & $\mathrm{~F}_{4} \mathrm{BC}_{3} \mathrm{~S}_{1}-1-6-3-15 \times \mathrm{S}-6524$ & 92.4 & 1.45 & 0.15 & 0 & 0.05 & 15.0 & 0.05 & 0 & 0.1 & 5.0 & 10.0 \\
\hline 11 & $\mathrm{~F}_{4} \mathrm{BC}_{3} \mathrm{~S}_{1}-1-6-3-15 \times \mathrm{S}-6530$ & 93.1 & 1.23 & 0.15 & 0 & 0.15 & 15.0 & 0 & 0.05 & 0.1 & 5.0 & 5.0 \\
\hline 12 & $\mathrm{~F}_{4} \mathrm{BC}_{3} \mathrm{~S}_{1}-1-6-3-15 \times \mathrm{S}-6532$ & 92.3 & 1.64 & 0.05 & 0 & 0.05 & 5.0 & 0.05 & 0 & 0.05 & 5.0 & 5.0 \\
\hline
\end{tabular}

Table 2. Dynamics of affection of cotton hybrids $\mathrm{F}_{6}$ by Helicoverpa armigera

\begin{tabular}{|c|c|c|c|c|c|c|c|c|c|c|c|c|}
\hline \multirow[b]{3}{*}{ № } & \multirow[b]{3}{*}{ Hybrids-combinations } & \multirow{3}{*}{ 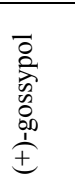 } & \multirow{3}{*}{ 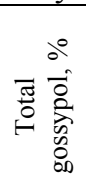 } & \multicolumn{4}{|c|}{ 1-Observation } & \multicolumn{4}{|c|}{ 2- Observation } & \multirow{3}{*}{$\begin{array}{l}\text { Average } \\
\text { degree of } \\
\text { affecting }\end{array}$} \\
\hline & & & & \multicolumn{3}{|c|}{ Density of population, 10 plants, $n$} & \multirow[b]{2}{*}{$\begin{array}{c}\text { Affected, } \\
\%\end{array}$} & \multicolumn{3}{|c|}{ Density of population, 10 plants, $n$} & \multirow[b]{2}{*}{$\begin{array}{c}\text { Affected, } \\
\%\end{array}$} & \\
\hline & & & & Eggs, $\mathrm{n}$ & $\begin{array}{c}\text { Caterpillars } \\
\mathrm{n}\end{array}$ & $\begin{array}{l}\text { Affected } \\
\text { buds, n }\end{array}$ & & Eggs, $n$ & $\begin{array}{c}\text { Caterpillars } \\
\mathrm{n}\end{array}$ & $\begin{array}{l}\text { Affected } \\
\text { buds, n }\end{array}$ & & \\
\hline 1. & $\mathrm{~F}_{6} \mathrm{BC}_{3} \mathrm{~S}_{1}-47-8-1-17 \times \mathrm{S}-6524$ & 91,1 & 0,65 & 12 & 1 & 3 & 13.0 & 1 & 3 & 9 & 4.0 & 8.5 \\
\hline 2. & $\mathrm{~F}_{6} \mathrm{BC}_{3} \mathrm{~S}_{1}-47-8-1-17 \times \mathrm{S}-6530$ & 91,8 & 1,03 & 14 & 2 & 8 & 16.0 & 2 & 4 & 15 & 6.0 & 11.0 \\
\hline 3. & $\mathrm{~F}_{6} \mathrm{BC}_{3} \mathrm{~S}_{1}-47-8-1-17 \times \mathrm{S}-6532$ & 91,8 & 1,32 & 16 & 1 & 5 & 17.0 & 3 & 5 & 11 & 8.0 & 12.5 \\
\hline 4. & $\mathrm{~F}_{6} \mathrm{BC}_{3} \mathrm{~S}_{1}-1-6-3-15 \times \mathrm{S}-6524$ & 90,0 & 1,12 & 18 & 3 & 6 & 21.0 & 2 & 6 & 13 & 8.0 & 14.5 \\
\hline 5. & $\mathrm{~F}_{6} \mathrm{BC}_{3} \mathrm{~S}_{1}-1-6-3-15 \times \mathrm{S}-6530$ & 90,8 & 1,45 & 6 & 0 & 0 & 6.0 & 0 & 2 & 6 & 2.0 & 4.0 \\
\hline 6. & $\mathrm{~F}_{6} \mathrm{BC}_{3} \mathrm{~S}_{1}-1-6-3-15 \times \mathrm{S}-6532$ & 91,0 & 0,87 & 10 & 0 & 2 & 10.0 & 1 & 0 & 4 & 1.0 & 5.5 \\
\hline 7. & $\mathrm{~F}_{6} \mathrm{BC}_{3} \mathrm{~S}_{1}-47-8-1-17 \times \mathrm{S}-6524$ & 77,6 & 0,89 & 7 & 0 & 4 & 7.0 & 0 & 2 & 0 & 2.0 & 4.5 \\
\hline 8. & $\mathrm{~F}_{6} \mathrm{BC}_{3} \mathrm{~S}_{1}-47-8-1-17 \times \mathrm{S}-6530$ & 74,4 & 1,23 & 6 & 2 & 8 & 8.0 & 0 & 5 & 13 & 5.0 & 6.5 \\
\hline 9. & $\mathrm{~F}_{6} \mathrm{BC}_{3} \mathrm{~S}_{1}-47-8-1-17 \times \mathrm{S}-6532$ & 78,4 & 0,92 & 8 & 0 & 3 & 8.0 & 1 & 2 & 9 & 3.0 & 5.5 \\
\hline 10. & $\mathrm{~F}_{6} \mathrm{BC}_{3} \mathrm{~S}_{1}-1-6-3-15 \times \mathrm{S}-6524$ & 75,4 & 0,91 & 17 & 4 & 8 & 21.0 & 2 & 8 & 15 & 10.0 & 15.5 \\
\hline 11. & $\mathrm{~F}_{6} \mathrm{BC}_{3} \mathrm{~S}_{1}-1-6-3-15 \times \mathrm{S}-6530$ & 77,3 & 1,16 & 10 & 1 & 3 & 11.0 & 1 & 3 & 9 & 4.0 & 7.5 \\
\hline 12. & $\mathrm{~F}_{6} \mathrm{BC}_{3} \mathrm{~S}_{1}-1-6-3-15 \times \mathrm{S}-6532$ & 78,0 & 0,68 & 12 & 2 & 4 & 14.0 & 1 & 5 & 8 & 6.0 & 10.0 \\
\hline 13. & $\mathrm{~F}_{6} \mathrm{~L}-10 / 04 \times \mathrm{BC}_{3} \mathrm{~S}_{1}-1-6-3-15$ & 81,0 & 1,19 & 20 & 3 & 7 & 23.0 & 3 & 6 & 15 & 9.0 & 16.0 \\
\hline 14. & $\mathrm{~F}_{6} \mathrm{~L}-10 / 04 \times \mathrm{BC}_{3} \mathrm{~S}_{1}-1-6-3-15$ & 70,0 & 0,98 & 5 & 1 & 2 & 6.0 & 0 & 3 & 5 & 3.0 & 4.5 \\
\hline
\end{tabular}


The results of studies of another group of hybrids developed between US accessions and Uzbek cultivars with a high level of $(+)$-gossypol in seeds showed that their affection related to the initial form genotype involved in hybridization.

For example, such hybrids with a low level of (+)gossypol in seeds as $\mathrm{F}_{3}$ Bukhoro- $8 \times \mathrm{BC}_{3} \mathrm{~S}_{1}-1-6-3-15$ $(62 \%), \mathrm{F}_{3}$ Turon $\mathrm{x} \mathrm{BC}_{3} \mathrm{~S}_{1}-1-6-3-15(67 \%), \mathrm{F}_{3}$ Surkhon -14 $x \mathrm{BC}_{3} \mathrm{~S}_{1}-1-6-3-15(79 \%)$ and $\mathrm{F}_{3} \mathrm{I}-9871 \times \mathrm{BC}_{3} \mathrm{~S}_{1}-1-6-3-15$ $(75 \%)$, developed from a relatively resistant parent form $\left(\mathrm{BC}_{3} \mathrm{~S}_{1}-1-6-3-15\right)$ with high (+)- gossypol in seeds $(93.8 \%)$, were affected with H.armigera in less degree (with respective affection $25 \%, 50 \%, 40 \%$ and $40 \%$ ).

Table 3. Tolerance hybrids with different levels of $(+)$ - gossypol in seeds to Helicoverpa armigera (in Petri dishes)

\begin{tabular}{|c|c|c|c|}
\hline № & Initial forms and hybrids & $\begin{array}{c}(+)-\underset{\%}{\text { gossypol, }} \\
\%\end{array}$ & $\begin{array}{c}\text { Affected, } \\
\%\end{array}$ \\
\hline 1. & S-6524 & 77.0 & 55,0 \\
\hline 2. & S-6530 & 70.0 & 45,0 \\
\hline 3. & S-6532 & 75.0 & 55,0 \\
\hline 4. & L-10/04 & 61.0 & 40,0 \\
\hline 5. & $\mathrm{BC}_{3} \mathrm{~S}_{1}-47-8-1-17$ & 93.3 & 45,0 \\
\hline 6. & $\mathrm{BC}_{3} \mathrm{~S}_{1}-1-6-3-15$ & 93.8 & 35,0 \\
\hline 7. & $\mathrm{~F}_{3}$ Turon $\mathrm{x} \mathrm{BC}_{3} \mathrm{~S}_{1}-47-8-1-17$ & 62,0 & 75,0 \\
\hline 8. & $\mathrm{~F}_{3}$ Turon $\times \mathrm{BC}_{3} \mathrm{~S}_{1}-1-6-3-15$ & 67,0 & 50,0 \\
\hline 9. & $\mathrm{~F}_{3}$ Bukhoro-8 $\times \mathrm{BC}_{3} \mathrm{~S}_{1}-47-8-1-17$ & 64,0 & 65,0 \\
\hline 10. & $\mathrm{~F}_{3}$ Bukhoro $-8 \times \mathrm{BC}_{3} \mathrm{~S}_{1}-1-6-3-15$ & 62,0 & 25,0 \\
\hline 11. & $\mathrm{~F}_{3}$ Surkhon-14 x BC $\mathrm{B}_{1}-47-8-1-17$ & 75,0 & 50,0 \\
\hline 12. & $\mathrm{~F}_{3}$ Surkhon-14 x BC $\mathrm{S}_{1}-1-6-3-15$ & 79,0 & 40,0 \\
\hline 13. & $\mathrm{~F}_{3} 9871-\mathrm{I} \times \mathrm{BC}_{3} \mathrm{~S}_{1}-47-8-1-17$ & 60,0 & 65,0 \\
\hline 14. & $\mathrm{~F}_{3} 9871-\mathrm{I} \times \mathrm{BC}_{3} \mathrm{~S}_{1}-1-6-3-15$ & 75,0 & 40,0 \\
\hline 15. & $\mathrm{~F}_{5} \mathrm{BC}_{3} \mathrm{~S}_{1}-47-8-1-17 \times \mathrm{S}-6524$ & 90,9 & 55,0 \\
\hline 16. & $\mathrm{~F}_{5} \mathrm{BC}_{3} \mathrm{~S}_{1}-47-8-1-17 \times \mathrm{S}-6530$ & 92,8 & 65,0 \\
\hline 17. & $\mathrm{~F}_{5} \mathrm{BC}_{3} \mathrm{~S}_{1}-47-8-1-17 \times \mathrm{S}-6532$ & 92,0 & 60,0 \\
\hline 18. & $\mathrm{~F}_{5} \mathrm{BC}_{3} \mathrm{~S}_{1}-1-6-3-15 \times \mathrm{S}-6524$ & 91,3 & 60,0 \\
\hline 19. & $\mathrm{~F}_{5} \mathrm{BC}_{3} \mathrm{~S}_{1}-1-6-3-15 \times \mathrm{S}-6530$ & 91,8 & 50,0 \\
\hline 20. & $\mathrm{~F}_{5} \mathrm{BC}_{3} \mathrm{~S}_{1}-1-6-3-15 \times \mathrm{S}-6532$ & 91,5 & 85,0 \\
\hline 21. & $\mathrm{~F}_{5} \mathrm{BC}_{3} \mathrm{~S}_{1}-47-8-1-17 \times \mathrm{S}-6524$ & 78,0 & 35,0 \\
\hline 22. & $\mathrm{~F}_{5} \mathrm{BC}_{3} \mathrm{~S}_{1}-47-8-1-17 \times \mathrm{S}-6530$ & 77,1 & 30,0 \\
\hline 23. & $\mathrm{~F}_{5} \mathrm{BC}_{3} \mathrm{~S}_{1}-47-8-1-17 \times \mathrm{S}-6532$ & 80,1 & 15,0 \\
\hline 24. & $\mathrm{~F}_{5} \mathrm{BC}_{3} \mathrm{~S}_{1}-1-6-3-15 \times \mathrm{S}-6524$ & 76,3 & 45,0 \\
\hline 25. & $\mathrm{~F}_{5} \mathrm{BC}_{3} \mathrm{~S}_{1}-1-6-3-15 \times \mathrm{S}-6530$ & 71,5 & 35,0 \\
\hline 26. & $\mathrm{~F}_{5} \mathrm{BC}_{3} \mathrm{~S}_{1}-1-6-3-15 \times \mathrm{S}-6532$ & 69,0 & 20,0 \\
\hline 27. & $\mathrm{~F}_{6} \mathrm{BC}_{3} \mathrm{~S}_{1}-1-6-3-15 \times \mathrm{S}-6524$ & 71,9 & 30,0 \\
\hline 28. & $\mathrm{~F}_{6} \mathrm{BC}_{3} \mathrm{~S}_{1}-1-6-3-15 \times \mathrm{S}-6530$ & 76,7 & 35,0 \\
\hline 29. & $\mathrm{~F}_{6} \mathrm{BC}_{3} \mathrm{~S}_{1}-1-6-3-15 \times \mathrm{S}-6532$ & 78,5 & 40,0 \\
\hline 30. & $\mathrm{~F}_{6} \mathrm{BC}_{3} \mathrm{~S}_{1}-47-8-1-17 \times \mathrm{S}-6524$ & 91,2 & 75,0 \\
\hline 31. & $\mathrm{~F}_{6} \mathrm{BC}_{3} \mathrm{~S}_{1}-47-8-1-17 \times \mathrm{S}-6530$ & 91,4 & 55,0 \\
\hline 32. & $\mathrm{~F}_{6} \mathrm{BC}_{3} \mathrm{~S}_{1}-47-8-1-17 \times \mathrm{S}-6532$ & 93,1 & 70,0 \\
\hline 33. & $\mathrm{~F}_{6} \mathrm{BC}_{3} \mathrm{~S}_{1}-1-6-3-15 \times \mathrm{S}-6524$ & 92,1 & 55,0 \\
\hline 34. & $\mathrm{~F}_{6} \mathrm{BC}_{3} \mathrm{~S}_{1}-1-6-3-15 \times \mathrm{S}-6530$ & 92,4 & 60,0 \\
\hline 35. & $\mathrm{~F}_{6} \mathrm{BC}_{3} \mathrm{~S}_{1}-1-6-3-15$ x S-6532 & 92,3 & 65,0 \\
\hline 36. & $\mathrm{~F}_{6} \mathrm{~L}-10 / 04 \mathrm{x} \quad \mathrm{BC}_{3} \mathrm{~S}_{1}-47-8-1-17$ & 80,0 & 60,0 \\
\hline 37. & $\mathrm{~F}_{6} \mathrm{~L}-10 / 04 \mathrm{x} \quad \mathrm{BC}_{3} \mathrm{~S}_{1}-47-8-1-17$ & 65,0 & 40,0 \\
\hline
\end{tabular}

Among the hybrids $\mathrm{F}_{5}$ with a high level of $(+)$ - gossypol in the seeds, only in one case the damage was $50 \%\left(\mathrm{~F}_{5} \mathrm{BC}_{3} \mathrm{~S}_{1}-1-6-3-15 \times \mathrm{S}-6530\right)$, and in the remaining cases susceptibility were $55-65 \%$.
In contrast to the above, hybrids of this generation with a low level of $(+)$ - gossypol in seeds, differed in relative tolerance to the H.armigera. For example, susceptibility of $\mathrm{F}_{5} \mathrm{BC}_{3} \mathrm{~S}_{1}-47-8-1-17 \times \mathrm{S}-6532$ and $\mathrm{F}_{5} \mathrm{BC}_{3} \mathrm{~S}_{1}-1-6-3-15 \mathrm{x}$ S-6532 - with low (+)-gossypol were $15 \%$ and $20 \%$, respectively. The remaining hybrids of this generation with a low level of (+)-gossypol were affected by a H.armigera from $30 \%$ up to $45 \%$ (Table 3 ).

Among the hybrids $F_{6}$, comparative resistance with a low level of $(+)$ - gossypol and a relatively high affection of buds with a high level of (+)-gossypol (over $90 \%)$ are also observed. For example, the damage of buds with a low (+)-gossypol was from $30 \%\left(\mathrm{~F}_{6} \mathrm{BC}_{3} \mathrm{~S}_{1}-1-6-3-\right.$ $15 \times$ S-6524) up to $40 \%\left(\mathrm{~F}_{6} \mathrm{BC}_{3} \mathrm{~S}_{1}-1-6-3-15 \times \mathrm{S}-6532\right.$ and $\left.\mathrm{F}_{6} \mathrm{~L}-10 / 04 \mathrm{x} \mathrm{BC}_{3} \mathrm{~S}_{1}-47-8-1-17\right)$, and with a high level of $(+)$ - gossypol - from 55\% $\left(\mathrm{F}_{6} \mathrm{BC}_{3} \mathrm{~S}_{1}-47-8-1-17 \times \mathrm{S}-6530\right.$ and $\left.\mathrm{F}_{6} \mathrm{BC}_{3} \mathrm{~S}_{1}-1-6-3-15 \times \mathrm{S}-6524\right)$ up to $70 \%\left(\mathrm{~F}_{6} \mathrm{BC}_{3} \mathrm{~S}_{1}-47-\right.$ $8-1-17 \times$ S-6532). The similar dates of damaging of buds with different levels of $(+)$ - gossypol were observed at hybrids $\mathrm{F}_{7}$.

\section{CONCLUSIONS}

Thus, on the basis of the obtained results of researches to tolerance cotton bollworm of different progenies which developed hybrids with the participation of genetically distant forms of cotton on the natural background was found that the progenies $F_{6}$ with high $(+)$-gossypol were relatively tolerant to bollworm in comparing to progenies with low level (+)-gossypol. These results indicate that the level of $(+)$ - gossypol does not significantly affect on resistance to Helicoverpa armigera.

Also, results of the study of comparative resistance to Helicoverpa armigera among hybrids of different generations petri dishes, it was established that progenies with a different levels of $(+)$ - gossypol, a definite pattern is observed for affection. Genotypes with a low level of (+)- gossypol are affected by Helicoverpa armigera to a certain extent less than hybrids with high (+)-gossypol level. Although, the incidence of the initial accession $\mathrm{BC}_{3} \mathrm{~S}_{1}-1-6-3-15$ of US with a high level of gossypol does not preclude the possibility of developing of resistant genotypes with a high level of (+)-gossypol, which requires additional studies in this direction.

\section{ACKNOWLEDGEMENTS}

This researches was supported by Foundation of the Ministry of Innovative Development of the Republic of Uzbekistan, under project KX-EA-KX-2018-65.

\section{REFERENCES}

[1] Stipanovic R.D, Puckhaber L.S, Bell A.A, Percival A.E, Jacobs J. (2005). Occurrence of (+)- and (-)gossypol in wild species of cotton and in Gossypium hirsutum var. marie-galante (Watt) Hutchison. J. Agric. Food. Chem. 53:6266-6271.

[2] Bottger G. T., Sheehan E. T., Lukefahr M. J. (1964). Relation of gossypol content of cotton plants to insect resistance. J. Econ. Entomol. 57:283-285. 
[3] Hedin P.A., Parrott W.L., Jenkins J. N. (1992). Relationship of glands, cotton square terpenoid aldehydes and other allelochemicals to larval growth of Helicoverpa virescens (Lepidoptera: Noctuidae). J. Econ. Entomol. 85:359-364.

[4] Rashidov M.I. Biological protection of tomatoes from a cotton bollworm. Tez. Doc. At the All-Union Meeting on the experience of introducing a biological method into an integrated system for protecting cotton from pests and diseases. Tashkent, 1982. - pp.104-106.

[5] Zhang J., Zhang S., Yuan J., Xu K. (1985). Comparison of action racemic and optically active $(-$ and + ) gossypols on HeLa cells. Zhongguo Yixue Kexueyuan Xuebao 7:384-387.

[6] Yang W.H., Ma L.H., Zhu H.Q., Xiang S.K. (1999). Effects of different gossypol enantiomers on growth and development of cotton bollworm (Helicoverpa armigera) and Fusarium wilt. Acta Gossypii Sinica, 11:31-34.
[7] Ganesean Sunilkumar, Le Anne M.Campbell, Lorraine Puckhaber, Robert D. Stipanovic and Keerti S. Rathore. (2006). Engineering cottonseed for use in human nutrition by tissue-specific reduction of toxic gossypol. November 28 , vol.103, - $48 \mathrm{pp}$.

[8] Shvetsova, L., Alibekova, C. and Em, E. (1989). Resistance of Varieties. Khlopok, 5:29-30.167171.

[9] Shvetsova, L.P., Em, E.E. (1991). Methods of estimation resistance of cotton cultivars and accessions to bollworm. Tashkent, - 24 pp.

[10] Dospekhov B.A. Methodology of field experiments. Moscow: Kolos, 1985. -351 pp.

\section{Creative Commons Attribution License 4.0 (Attribution 4.0 International, CC BY 4.0)}

This article is published under the terms of the Creative Commons Attribution License 4.0 https://creativecommons.org/licenses/by/4.0/deed.en_US 